\title{
TREATMENT AND PROGNOSIS OF PORTAL HYPERTENSION IN CHILDREN*
}

BY

\author{
V. PALTIA and M. SULAMAA \\ From the Surgical Department of the Children's Clinic, University of Helsinki, Finland
}

Profuse haematemesis in children almost always emanates from the enlarged oesophageal varices present in portal hypertension. The mortality in conservatively treated cases is still high; according to many published statistics about $40 \%$ within a few years of the first haematemesis. In surgically treated cases the mortality after various procedures is 20 to $30 \%$, the cause of death being recurrent bleeding.

At the Helsinki University Children's Clinic a total of 40 cases of portal hypertension has been treated since 1947, all of these patients having had haematemesis before admission. The average age of the patients at the start of the treatment was 7 years, the youngest patient being 1 year old and the oldest 14 years.

The acute haemorrhage was in most cases controlled with blood transfusions, one patient only dying from haematogenic shock. In only three cases was it necessary to apply Sengstaken-Blakemore's balloon tamponade.

On the basis of the therapeutic measures carried out, we have divided the patients into three groups:

(1) The splenectomy group comprising cases from earlier years and patients whose spleen had been removed elsewhere.

(2) Cases in which anastomosis of the veins was carried out in order to reduce the portal pressure.

(3) Cases treated with ligation of the bleeding oesophageal varices through thoracotomy, either primarily or after failure of other procedures.

There were 17 splenectomy cases, and of these only three remained symptom free during periods of observation of seven, nine and 13 years respectively. There was renewed haemorrhage in 14 patients and four patients died (Table 1).

Altogether 29 anastomoses of veins were carried out in 21 patients (Table 2). Splenorenal anastomosis was the commonest procedure, carried out

* A paper read at a meeting of the British Association of Paediatric Surgeons in Stockholm, September 1961.
17 times in connexion with extirpation of the spleen. Only one patient remained symptom free; bleeding recurred in 16 patients and of these two died.

It was possible to carry out a porta-caval anastomosis in five cases only, four of these remaining symptom free. However, the time of observation was short, the longest period of observation being two years only.

A so-called Clatworthy anastomosis between the superior mesenteric vein and the inferior vena cava was carried out in four cases, in three of which bleeding recurred.

TABLE 1 SPLENECTOMY

\begin{tabular}{c|c|c|c}
\hline $\begin{array}{c}\text { Follow-up } \\
\text { (years) }\end{array}$ & Symptomless & $\begin{array}{c}\text { Recurrent } \\
\text { Bleeding }\end{array}$ & Deaths \\
\hline 1 & & 1 & \\
2 & & 4 & 2 \\
3 & & 1 & 1 \\
4 & 1 & 1 & 1 \\
5 & 1 & & \\
6 & & & \\
7 & & & \\
9 & 1 & 10 & 4 \\
10 & 3 & & \\
12 & & & \\
13 & & & \\
\hline Totals & & & \\
\hline
\end{tabular}

TABLE 2

29 VENOUS SHUNTS CARRIED OUT IN 21 PATIENTS

\begin{tabular}{|c|c|c|c|c|}
\hline $\begin{array}{l}\text { Follow-up } \\
\text { (years) }\end{array}$ & $\begin{array}{l}\text { Symptom- } \\
\text { less }\end{array}$ & $\begin{array}{l}\text { Recurrent } \\
\text { Bleeding }\end{array}$ & Deaths & Total \\
\hline $\begin{array}{l}6 \text { mths } \\
1 \\
2 \\
3 \\
4 \\
5 \\
6 \\
7 \\
8 \\
9\end{array}$ & $\begin{array}{l}1 \\
1 \\
1 \\
1 \\
1\end{array}$ & $\begin{array}{l}2 \\
4 \\
5 \\
1 \\
2\end{array}$ & 2 & \\
\hline Totals & 5 & 14 & 2 & 21 \\
\hline
\end{tabular}

There were 17 lieno-renal shunts, five porta-caval shunts, four Clatworthy and three others. 
TABLE 3

LIGATION OF OESOPHAGEAL VARICES

\begin{tabular}{c|c|c|c}
\hline $\begin{array}{c}\text { Follow-up } \\
\text { (years) }\end{array}$ & $\begin{array}{c}\text { Symptom- } \\
\text { less }\end{array}$ & $\begin{array}{c}\text { Recurrent } \\
\text { Bleeding }\end{array}$ & Deaths \\
\hline 6 mths & 1 & 2 & \\
1 & 2 & 2 & \\
2 & 2 & & \\
3 & 4 & 1 & \\
4 & 1 & 1 & \\
6 & 2 & & \\
7 & 1 & & \\
8 & 1 & & 0 \\
9 & 17 & 6 & \\
\hline Totals & $\cdots$ & 1 & \\
\hline
\end{tabular}

In the three remaining cases lesser peripheral anastomoses were carried out and all of them proved inadequate.

Thus, after a shunt operation haematemesis recurred in about $70 \%$ of cases. The general experience is that a venous anastomosis of small calibre does not remain patent for any length of time, or is incapable of reducing the portal pressure sufficiently.

In only about $10 \%$ of cases do the anatomical conditions in children permit a porta-caval shunt.

In 23 cases ligation through thoracotomy of the submucous varices in the oesophagus was carried out (Table 3 ), this procedure being repeated several times in five patients. Of these cases, 17 , i.e. threequarters, remained symptom free during a period of
TABLE 4

BLEEDING OESOPHAGEAL VARICES IN A TOTAL OF 40 CASES

\begin{tabular}{|c|c|c|c|}
\hline & Symptomless & Bleeding & Deaths \\
\hline $\begin{array}{l}\text { Splenectomy } \\
\text { Shunts } \\
\text { Ligation of varices } \\
\text { Primary fatal bleed- } \\
\text { ing or gastrec- } \\
\text { tomy }\end{array}$ & $\begin{array}{r}3 \\
5 \\
17\end{array}$ & $\begin{array}{r}10 \\
14 \\
6\end{array}$ & $\begin{array}{r}4 \\
2 \\
-\end{array}$ \\
\hline Total .. & 25 & & 9 \\
\hline
\end{tabular}

Total deaths, 9; symptomless, 25 ; bleeding after last procedure (ligation of varices) 6; giving a total of 40 .

observation varying between six months and nine years. Bleeding recurred in six patients, but later bleedings were less profuse than those occurring before ligation. No patients in this group died.

Simultaneously with ligation three patients had their spleens transposed from the abdominal to the thoracic cavity so as to encourage the formation of new collaterals. During the period of observation, which varied from six to 20 months, the results have been satisfactory.

In three other cases a transposition of the spleen into the thoracic cavity was performed together with ligation of the oesophageal varices. In the postoperative splenoportography (Figs. 1 and 2) a rich network of collaterals is shown above the transposed spleen.

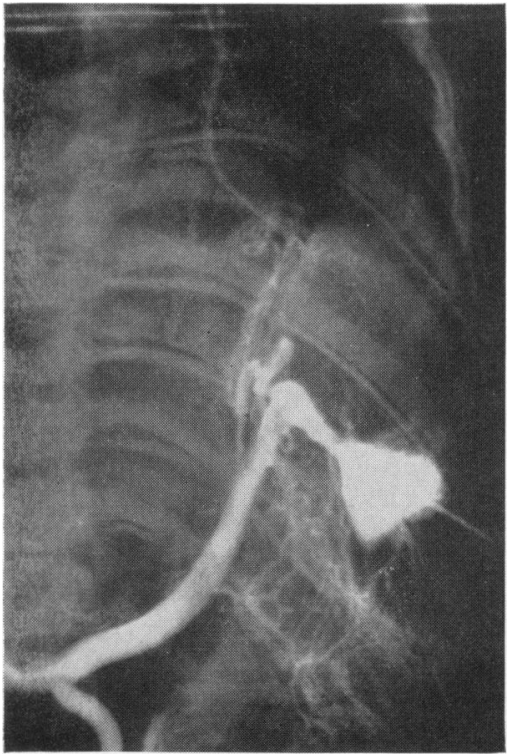

FIG. 1.-Postoperative transpleural splenography in a patient with transposition of the spleen into the thoracic cavity. Wide intercostal veins and a large collateral functioning as shunts.

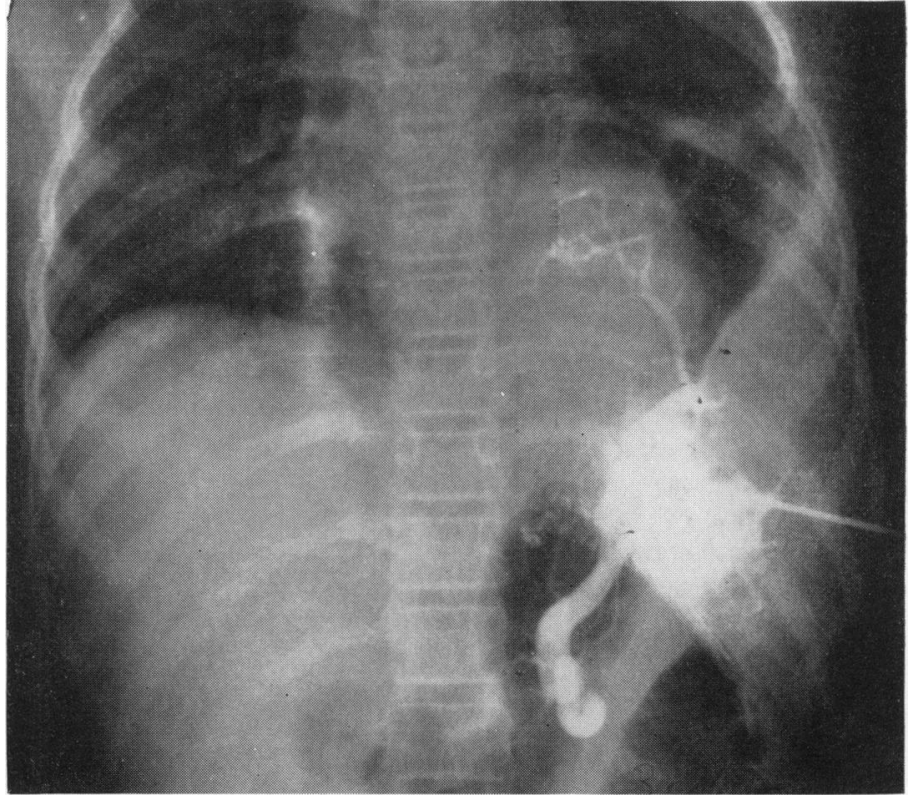

FIG. 2.-Another patient with the same procedure: large collaterals inside the thoracic wall. 
Of our 40 patients, 31 , or $77.5 \%$, are alive; the longest period of observation is 13 years, the average being four years (Table 4). Splenorenal anastomosis cannot as a rule prevent repeated haemorrhage. If splenoportography demonstrates that anatomical conditions will permit porta-caval anastomosis, this treatment should be considered.

If porta-caval anastomosis is not possible, the transposition of the spleen into the thoracic cavity is indicated together with ligation of the oesophageal varices.

With the exception of anaemia resulting from hypersplenism, patients with portal hypertension have no symptoms. Prevention of bleeding must, therefore, be considered the only indication for therapy, and ligation of the oesophageal varices must be considered as effective a measure as other procedures which aim at a reduction of the portal pressure. 